\title{
Demand Planning Information Sharing: N ZAR
}

\author{
Nontobeko Nontokozo Mtshali, Thokozani Patmond Mbhele* and Nkechi Dorothy Neboh
}

\author{
Discipline of Supply Chain Management, School of MIG, University of KwaZulu-Natal (Westville), Private Bag \\ X54001, Durban, 4000, South Africa
}

\begin{abstract}
Organisations are currently faced with difficulties in effectively aligning demand plans to the volatile environments in which they operate. While operating environments and consumer needs change, capacity capabilities often do not reflect the demand plans. The absence of alignment results in inaccurate forecasts, thus putting the longterm sustainability of a business at risk. The focus and aim of the study is to understand how demand planning information are shared at N ZAR for optimal performance. A quantitative explorative case study research design is being used and data was collected through a structured self-administered questionnaire in this study. The sample size was 86 , which comprised of employees from Demand and Supply Planning, Finance and Control, Sales and Marketing divisions. The sample includes top management, middle management, first level management and non-management. Data analysis uses descriptive and multivariate statistics. The study findings show most of the participants responded positively to the statements that information sharing achieves demand chain coordination. This study recommended that top management should provide full support to information sharing initiatives to facilitate the demand planning process.
\end{abstract}

Keywords: Capacity, constraints, demand chain, forecasting, information sharing.

\section{INTRODUCTION}

The continually changing marketplace puts a great deal of pressure on businesses to meet the demands of their customers, while at the same time achieving their projected targets. With increasing competition and fluctuating demand, companies more than ever need to increase their level of accuracy when it comes to demand planning (Grimson \& Pyke 2007, 354). Increased competition and economic instability result in a continuously fluctuating demand. This places pressure on companies to develop new strategies to improve the level of efficiency in their supply chains while reducing overall costs (Browning and Heath, 2009). Demand chain management needs to be managed in an environment characterised by uncertainty, dynamism and complexity, for instance the fast-moving consumer goods industry. Demand chain management has been highlighted to be a strategy in business that allows the alignment of demand and supply from the customer, supply chain partners and supply chain channels (Deshmukh \& Mohan, 2016, 20), hence resources must be effectively utilised. It makes sense for businesses to have prior plans and decisions on how to trade, conduct their business and retain customer base. This means that at every point in a supply chain, the demand requirements need to be addressed to create a successful business synergy. Organisations need to review their operating models to ensure that they are responsive to the increasingly complex demand of business (Loretto, 2014, 5). While

*Address correspondence to this author at the Discipline of Supply Chain Management, School of MIG, University of KwaZulu-Natal (Westville), Private Bag X54001, Durban, 4000, South Africa; Tel: +2731 260 7524;

E-mail: mbhelet@ukzn.ac.za effective capacity planning is one mechanism that can be used to achieve efficiency and reduced costs (Bakke \& Hellberg 1993, 254), one of the main challenges of achieving effective demand planning is information sharing within a company.

The focus of demand chain management is ensuring the customers' needs are ensured and handled well, hence facilitating a lasting relationship. In delivering customer's needs, organisations put varied plans in place to meet up set objectives. According to Szozda, and Werbinska-Wpjciechowska (2013) quality of demand planning depicts a business performance. Trust and loyalty can be built with customers, and this prompts the quality and type of information that is shared. This information must be accessed by every supply chain partners and even within the entire company information can be shared harmoniously to ensure right decisions are made. The type of information shared can assist retailers to make decisions on forecasting, quantity of goods to keep and time to launch products to the market. Agrawal (2012, 203) echoed that demand chain management focuses on the instant flow of demand-associated information from the end customers to the point where it is used (the vendors) with the notion of optimally using the marketing functions of distribution to ensure that value is created in the supply chain. However, as the 21 st century continues to evolve, the environments in which organisations operate are characterised by increasing competitiveness, globalisation pressures and sustainability requirements. These put pressure on companies to implement strategies to meet the demand with minimal resources and at the lowest cost to the business. Nonetheless, some organisations have 


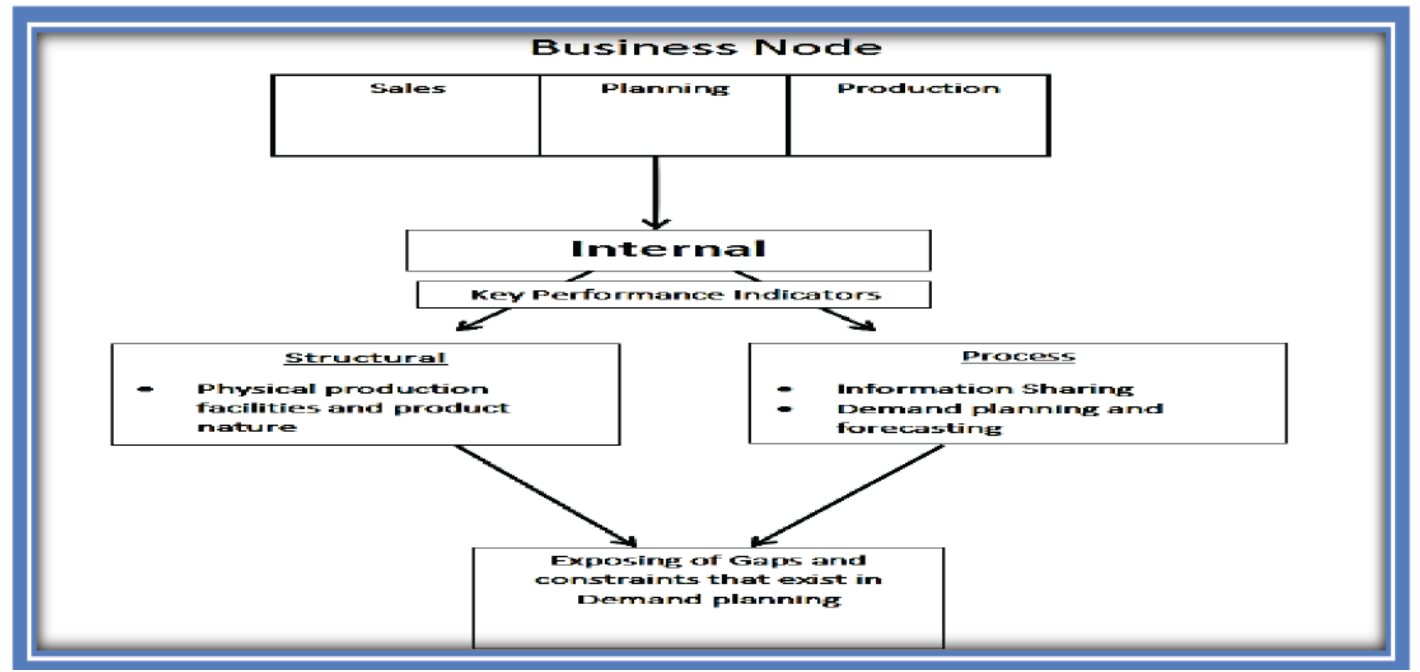

Figure 1: Holistic Demand Planning Approach.

Source: Nielsen \& Steger-Jensen (2006).

trouble in effectively sharing information on demand planning. The lack of information is likely to result in unreliable and inaccurate forecasting, increased supply chain cost ultimately putting the long-term viability of the business at risk. This study aims to investigate the extent at which information on demand planning is shared to improve the demand chain performance. To be successful, a business must have reliable plans and accurate forecasts in place, not only to identify potential business opportunities, but also to have the capability to exploit these opportunities. One of the biggest challenges to an organisation is being able to accommodate variability in demand and match supply with demand. And as such be able to share vital information to forecast demand optimally. The question then is, what is the extent of sharing demand planning information to improve demand chain performance? The significance of this study lies in the fact that there is dearth of information on demand chain management and as such, this study will attempt to address the gap.

\section{THEORETICAL FRAMEWORK}

\section{Holistic Demand Planning Framework (HDPP)}

The Holistic Demand Planning approach has been derived from the Hierarchical Demand Planning Approach (HDPA), first presented 1975 by $\mathrm{Hax}$ and Meal and further developed in 2006 by Nielsen and Steger-Jensen to tailor demand plans to multiple perspectives and objectives with demand planning success occurring when there is a match between systems. The Holistic Demand Planning (HDP) theory links both internal and external structures and process and should be coordinated by identifying several relevant stakeholders, considering the external context as well as various objectives (Nielsen \& Steger-Jensen 2006, 6).

\section{LITERATURE REVIEW}

\section{N ZAR}

This investigation is on a company known as $\mathrm{N}$ ZAR, which is a South African FMCG company that manufactures quality products for human consumption. It is one of the world's leading nutrition, health and wellness company. N ZAR has been in existence for a long time and is one of the leading companies in consumable goods. It has had a dependably strong market presence and is characterised by ever growing and changing product lines that aim to meet consumer demands. In recent years, however, N ZAR has been faced with challenges related to sharing of demand planning information that can assist to meet the demand of its customers.

\section{Dynamics of Chain Management}

To ensure demand chain management, employment and integration of technology tools is required in order to consolidate demand and share data amongst planning and control functions (Frohlich \& Westbrook 2002, 732). By doing so, organisations can be more responsive to demand and reduce waste and returns (Christopher \& Rayls 2014, 29). The shift in supply chains to demand chains is highly driven by market forces and development in new technologies (Christopher \& Rayls 2014, 29), and the advancement of technology and internet have made this integration a 
possibility, providing access to real time demand information and information visibility (Frohlich \& Westbrook 2002, 729). Integrated business planning is an enabler for much closer alignment of supply and demand (Smith, Andraski \& Fawcett 2011, 5; Stank et al. 2012, 179). It is thus important that there is a control in place for the distortion of information as it is amplified moving up the supply chain (Lee et al. 2004, 1882). One way to mitigate this risk is by balancing supply and demand across the supply chain, this requires flow of data between the integrated suppliers and buyers (Frohlich, 2002, 539; Chan \& Chan 2009, 2).

\section{Demand Planning}

In a business, planning towards demand is the first step to subsequent process, including purchasing, production and distribution (Szozda et al. 2013, 77). One of the main issues within supply chain is predicting future demand, as the information that the upstream has, is not always what is necessarily required in the downstream. Supply chain performance is largely dependent on the quality of demand plans (Szozda et al. 2013, 77). For instance, Jung \& Jeong $(2012,5416)$ identified that there is a relationship between the levels of early information received and forecasting performance, as well as the amount of investment obtained thereafter. Furthermore, (Triple point technologies 2012) conducted research on reducing the level of risk in the demand planning process, and found out that developing a feasible, constrained and profitable demand plan, is essential in the current environment. Demand planning is thus a representation of procedures and information sharing mechanisms used to fully optimise forecast in the demand planning process (Vlckova \& Patak 2011,1000), hence improving decisions made on size of production, inventory levels, the utilisation of resources and capacity, leads to an organisation's profit maximisation. The importance of demand planning is ever so increasing as it is a differentiating factor of customer relationship management and supply chain management (Kilger \& Wagner 2010,135). Therefore, demand planning can be a strategic process that ensures that the right product is available at the right time and place.

\section{Information Sharing}

Sharing information in any organisation is vital to the success of the business. information sharing cascades from the downstream side of the supply chain (end customers) to the upstream side (suppliers). A good enough information shared reduces the cost of holding inventory and shrinkage in businesses such as the FMCG industry. Hence, it is important that the number of inventories to be held by businesses, is planned for. It is in planning towards what to buy and how to trade such, that businesses forecast optimally. Planned information on demand improves the management of inventory. Information sharing can be used to access vital information on the status of products and materials in terms of flow, on the supply chain (Jonsson \& Mattson 2013,3). Although advancements in technology have propelled the opportunity of information sharing, variables of aligned vision amongst planning partners, communication, trust, reciprocity, power amongst members and support from all levels of management need to be considered as influences in the quality of the information shared amongst supply chain partners (Wu et al. 2014, 123). In contrast to this, Shou, Yang, Zhang \& Su (2013, 2137) explains that in markets that are characterised with abundant opportunity, firms become motivated to share information with partners in order to capture opportunities for market growth. Low levels of information sharing within companies, occur as a result of inefficient coordination of actions amongst business units (Lotfi et al. 2013, 298). The greatest value of information sharing is the benefits that are gained, which outweigh the associated costs ( $\mathrm{Li}$ et al. 2001, 34).

\section{Influencers on Information Sharing}

Various factors influence the information that is shared in businesses and is discussed below

\section{Inventory Control Polices}

Policies on replenishing inventory in businesses such as FMCG is known as the main cause of bullwhip effect (Constantino, Di Gravio, Shaban \& Tronci 2014, 292). It is expected that a constant check is made on the available inventory to plan a future purchase. Inventory control policy ensures that everything that has to do with inventory management is abided to, such as purchasing of materials and goods.

\section{Interaction between Demand Planners}

Demand planners must interact with each other hence the essence of information sharing is achieved. Information should be grasped on the instance that it is delivered so that the actual benefit is shared. Kumar, Singh \& Shankar (2014) highlighted that when 
organisations network with suppliers and customers, and have frequent departmental meeting enhances collaboration.

\section{Shared Vision between Demand Planning Partners}

All supply chain partners must have a common objective for the business. An objective that can be shared and can be beneficial to every member in the chain. When it comes to the demand planners, it is important that information on the capacity of resources, inventory level and how to offer better services to customers, is shared. This information allows for better demand forecast.

\section{Trust}

Virtually information shared is assumed to be safe with the recipient. Relationships are improved when trust is in place (Abdullah \& Musa 2014, 266). A literature evidence indicates that trust and collaboration positively associate with information sharing and will reduce supply chain bullwhip effect (De Almeida, Marings, Salgado, Santos \& Da Silva 2017, 203).

\section{Top Management Support}

Top management ensures that every decision taken are initiated throughout the organisations. In enabling success in information sharing, management communicates their vision for the business hence building trust in the organisation (Septer 2013). Management must be committed to share information amongst employees. Disseminating information to lower level employees is important as their services is directly related to the business customers.

\section{Managing Demand Planning Collaboration Through Reliable Information Sharing}

Information exchange is the key to managing physical product flow through the supply chain, as well as reducing costs and improving service performance of enterprises (Wu, Chuang, \& Hsu 2014, 125). It is an indispensable tool for survival of businesses and an enabler of supply chain integration (Lotfi, Mukhtar, Sahran \& Zadeh 2013, 298). In a supply chain, a prominent dominating issue regarding collaboration is the level and type of information that can be shared amongst partners (Montoya-Torres \& Ortiz-Vargas 2014, 347).

Several authors (Lotfi et al. 2013, 299; Kocoglu, Imamoglu \& Keskin 2011, 1630) have identified benefits of information sharing, such as better understanding of the customer and having the ability to anticipate potential market changes. Supply chain leaders are currently using information integration to produce significant performance improvements. This includes faster product developments, reduced lead times and higher flexibility in supply (Cachon \& Fisher 2000; Clark \& Hammond 1997; Fawcett, Magnan, \& McCarter 2008; Frohlich 2002; Hong \& Rao 2010; Hult, Ketchen, \& Slater 2004; Radjou 2003). The integration of information allows for connectivity in the supply chain but does not guarantee the protection of information that is shared (Zhu et al. 2014, 7). Partners are more willing to provide information on forecast and sales but are hesitant to share some strategic and sensitive information, as supply chain members may choose to use it to their advantage (Fawcett, Wallin, Allred \& Magnan 2009, 224). The unwillingness to share such information, contravene the benefits that arise from investments made from information sharing and relationships, as there is unclear decision-making quality (Fawcett, Wallin, Allred, Fawcett \& Magnan 2011, 39).

\section{Integrating the Supply Chain for Collaborative Relationships}

Collaboration is critical to the success of any supply chain (Chong, Ooi, \& Sohal 2009, 154). Collaboration in the supply chain is established when there is a level of trust, communication, information sharing and interdependence amongst members of the supply chain (Wu \& Chaung 2010, 304 Chong et al. 2009, 315). This collaborative relationship creates the opportunity for supply chain partners to share information on forecast data (Chong et al. 2009, 315). Researchers (Wu \& Chuang 2010; Chong \& Ooi 2008; Chong et al. 2009 \& Tsung 2002) recognised that information sharing and integrating the supply chain, is a vital prerequisite for a collaborative relationship to be developed. A collaborative relationship is a combination structure that entails a few relationship attributes such as peer pressure, transaction climate and level of uncertainty (Wu \& Chang 2010, 306). Research has shown that a firm needs to integrate information systems with key supply chain partners, in order to facilitate improved information sharing and data exchange (Hult, Ketchen, \& Arrfelt 2007, 1037). The external integration with customers and suppliers is concurrently related to the internal integration commitment to these customers and suppliers (Zhao, Huo, Selen \& Yeung 2011, 22). This means that internal integration makes external integration possible through developing capabilities to integrate systems, data and processes. Once this has been achieved, 
external integration can occur (Zhao et al. 2011, 22). Information sharing can thus be applied for both internal and external integration (Montoya-Torres \& Ortiz-Vargas, 2014; Zhao et al. 2011).

\section{Research Strategy and Techniques}

This article combines the use of theoretical framework with field investigations. Based on this the research approach chosen was quantitative. This study therefore used non-probability sampling, where the elements in the population do not have any probabilities associated with being selected as sample subjects (Sekaran \& Bougie, 2013, 132). The target sample size is 155 with target population of 256 . This study used an exploratory case study design which assisted in demand planning information sharing in $\mathrm{N}$ ZAR. It therefore seemed beneficial to incorporate the case study into the research design as it assisted the researcher in understanding the underlying issues in the study. This design was relevant to this study objective, as the impact of information sharing on outcomes of demand plans is not a widely explored phenomenon and very little literature is available on this topic. It adopted purposive convenience sampling technique, which involves selecting those participants who are accessible and in the best position to provide the required information on demand planning operations (Sekaran \& Bougie 2013, 132). For the purposes of this study, the research was conducted at $N$ ZAR Head Offices based in Bryanston, Johannesburg, in the Gauteng region, including its factories and distribution centres. Data was gathered using questionnaire to elicit responses. The SPSS programme was used to analyse the findings. N ZAR is based in five provinces, including Gauteng, KwaZuluNatal, Eastern Cape, Western Cape and North West Province. The population of the study included all employees in three divisions, who were working in Gauteng at the time of this study: Demand and Supply Planning (26), Finance and Control (200) and Sales and Marketing (30). Of the population of 256, a recommended minimum sample size was 155 , deduced from (Sekaran \& Bougie 2013, 22) table. However, only 86 respondents submitted a completed questionnaires. Cronbach's Alpha coefficient was used to measure reliability and the value was 0.84 which is regarded as acceptable.

\section{Data Analysis}

This item intended to establish the factors respondents perceived as the most critical factors that influence information sharing in the organisations. Top management support is a critical factor that influences information sharing in the organisations. Other variables that followed include shared vision between demand planning partners, trust among internal and external partners, frequent interaction between demand planners and difference in inventory control policies.

\section{Information Sharing}

From the order of response, quality information sharing contributes positively to higher demand accuracy. Others responses that followed include: integrated electronic demand chain management systems improve information sharing, information sharing achieves demand chain coordination and improves collaborative demand planning, information velocity improves functional information flow on demand planning process, adequate Information technology IT infrastructure (structural) to facilitate information sharing across stake holders and finally, quality data inputs required for demand plans are received from relevant stake holders.

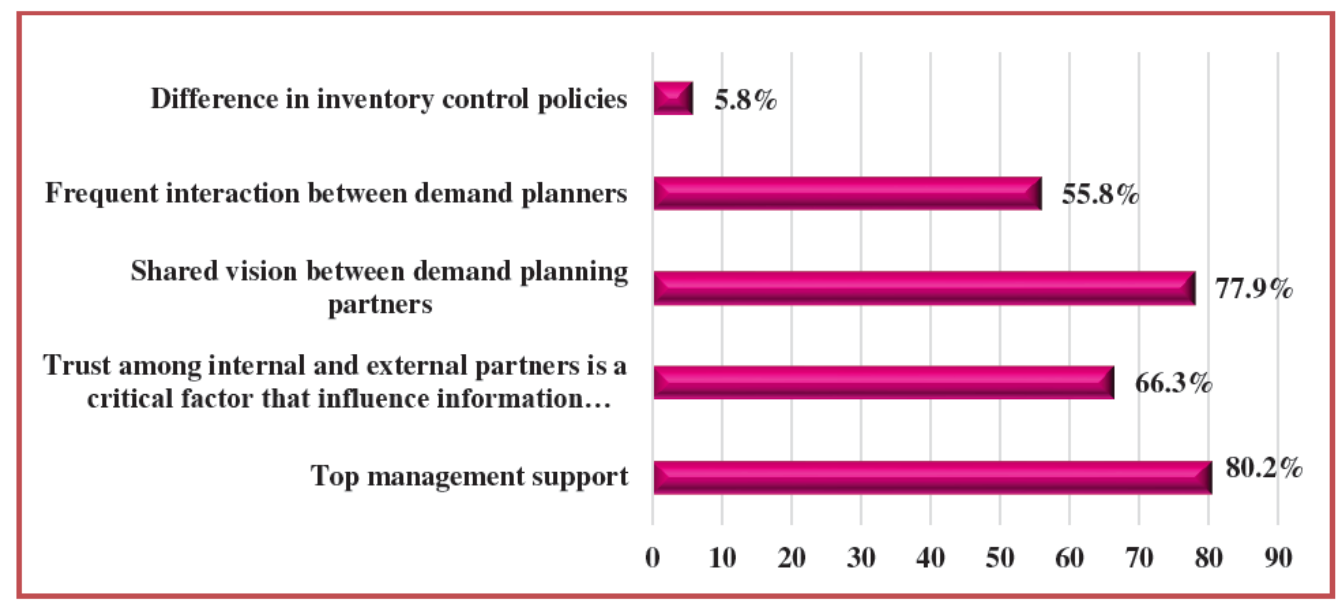

Figure 2: Critical factors influencing information sharing in the organisation. 
Table 1: Information Sharing

\begin{tabular}{|c|c|c|c|c|c|c|c|c|c|c|}
\hline & \multicolumn{2}{|c|}{ SD } & \multicolumn{2}{|c|}{ D } & \multicolumn{2}{|c|}{$\mathbf{N}$} & \multicolumn{2}{|c|}{ A } & \multicolumn{2}{|c|}{ SA } \\
\hline & $F$ & $\%$ & $\mathbf{F}$ & $\%$ & $F$ & $\%$ & $F$ & $\%$ & $\mathbf{F}$ & $\%$ \\
\hline $\begin{array}{c}\text { Information sharing achieves demand chain } \\
\text { coordination and improves collaborative demand } \\
\text { planning }\end{array}$ & 1 & 1.2 & 0 & 0 & 7 & 8.1 & 32 & 37.2 & 46 & 53.5 \\
\hline $\begin{array}{l}\text { Quality information sharing contributes positively to } \\
\text { higher demand planning accuracy }\end{array}$ & 1 & 1.2 & 0 & 0 & 1 & 1.2 & 15 & 17.4 & 69 & 80.2 \\
\hline $\begin{array}{l}\text { Integrated electronic demand chain management } \\
\text { systems improve information sharing }\end{array}$ & 1 & 1.2 & 0 & 0 & 9 & 10.5 & 50 & 58.1 & 26 & 30.2 \\
\hline $\begin{array}{l}\text { Information velocity improves functional information flow } \\
\text { on demand planning processes }\end{array}$ & 1 & 1.2 & 1 & 1.2 & 21 & 24.4 & 45 & 52.3 & 18 & 20.9 \\
\hline $\begin{array}{c}\text { Adequate IT infrastructure (Structural) to facilitate } \\
\text { information sharing across stakeholders (Planners, } \\
\text { Sales and Production) }\end{array}$ & 1 & 1.2 & 4 & 4.7 & 21 & 24.7 & 41 & 48.2 & 18 & 21.2 \\
\hline $\begin{array}{l}\text { Quality data inputs required for demand plans are } \\
\text { received from relevant stakeholders }\end{array}$ & 3 & 3.5 & 25 & 29.1 & 18 & 20.9 & 33 & 38.4 & 7 & 8.1 \\
\hline
\end{tabular}

\section{Perceptions on Demand Chain Planning}

The respondents had an option of selecting yes or no in response to the items on general perceptions on demand chain planning. The results were skewed to one side with the majority of the respondents perceiving demand chain planning positively (See Table 2). All the participants $(100 \% ; n=86)$ responded positively to the item that the advancement of technology have made internal network integration accessible to real time demand information visibility. About $98.8 \%$ (85) indicated that the extent of sharing demand planning information improves demand chain performance and $98 \%(n=84)$ stated that collaborative planning and replenishment links sales and marketing information to demand chain planning and execution processes. About $97.7(n=84)$ stated that collaborative demand planning utilises information shared by different functions in an organisation to achieve a one number forecast amongst the functions. About $96.5 \%$ $(n=82)$ of the responded stated that collaborative planning and replenishment in your company is a tool used to achieve lower inventories, logistical costs and create efficiencies and that capacity decisions

Table 2: General Perceptions of Demand Chain Planning

\begin{tabular}{|c|c|c|}
\hline & \multicolumn{2}{|c|}{ Yes } \\
\hline & Freq. & $\%$ \\
\hline The process of demand planning determines the capabilities of physical production facilities & 69 & 80.2 \\
\hline The extent of sharing demand planning information improves demand chain performance & 85 & 98.8 \\
\hline $\begin{array}{l}\text { The effectiveness of collaborative demand planning and forecasting influences the capability and utilisation of business } \\
\text { capacity }\end{array}$ & 80 & 93.0 \\
\hline $\begin{array}{l}\text { The company is able to link customers and suppliers together into closely integrated networks through demand chain } \\
\text { management }\end{array}$ & 73 & 84.9 \\
\hline $\begin{array}{l}\text { Demand chain management is a practice that manages collaboration and coordinates planning and forecasting } \\
\qquad \text { activities }\end{array}$ & 64 & 74.4 \\
\hline $\begin{array}{c}\text { The advancement of technology have made internal network integration accessible to real time demand information } \\
\text { visibility }\end{array}$ & 86 & 100.0 \\
\hline Demand planning is the process of forecasting how a product will sell and meet customer needs & 78 & 90.7 \\
\hline Demand planning is a business process that predetermines future demand for both products and service levels & 81 & 94.2 \\
\hline Demand planning is the business that assists in the aligning of production and distribution capabilities & 80 & 93.0 \\
\hline Demand planning is the business that assists in the aligning of production and distribution capabilities. & 65 & 75.6 \\
\hline Demand planning is the mechanism by which an organisation can foresee potential risks in the supply chain & 79 & 91.9 \\
\hline Demand planning provides a company with an opportunity to redesign its forecasting process & 72 & 83.7 \\
\hline
\end{tabular}


generally determine capital requirements, which take up a share of a company's fixed costs, and also indicated that the company is able to formulate their demand plans collaboratively to improve the accuracy of their forecasts.

About $94.2 \%(n=81)$ stated that demand planning is a business process that predetermines future demand for both products and service levels. Ninety-three percent $(n=80)$ stated that demand planning is the business that assists in the aligning of production and distribution capabilities. About $92.9 \%(n=79)$ stated that demand planning is the mechanism by which an organisation can foresee potential risks in the supply chain. About $90.7 \%$ (78) of the respondents indicated that demand planning is the process of forecasting how a product will sell and meet customer needs.

\section{RESEARCH RESULT DISCUSSION}

The extent to which sharing demand planning information improves demand chain performance.

\section{Factors that Influence Information Sharing}

Many of the respondents had strong views on two factors that influence information sharing in the organisation: level of information sharing and support from top management. Trust amongst internal and external partners as well as frequent interactions between demands planners were strongly supported as influencing factors. This indicates that to facilitate information sharing in the organisations top managements should provide enough support and a shared vision should exist amongst demand planning partners. Variables of aligned vision amongst planning partners, communication, trust, reciprocity and power amongst members and support from all levels of management need to be considered as influences in the quality of the information shared amongst supply chain partners (Wu et al. 2014, 123). Lotfi et al. (2013, 298) also support the view that communication amongst partners and efficient coordination amongst business units is important to achieve valuable information sharing. In contrast, Shou et al. (2013, 2137) states that in markets that are characterised with abundant opportunity, focus is less on the influencing factors and information sharing is highly motivated by opportunities of achieving market growth.

\section{Information Sharing in the Demand Planning Process}

Under general perceptions of demand planning process, several variables were taken into consideration that relate to information sharing. Wu et al. $(2014,123)$ states that in the demand chain, the advancement of technology has propelled the level of information sharing amongst planning partners. In today's operating environment, to improve the level of competitive advantage, supply chain partners have adopted networking concepts in order to facilitate information sharing (Ho et al., 2002, 4418). Promoting quality information sharing in the planning process produces significant performance improvements, this includes faster product developments, reduced lead times and higher flexibility in supply (Cachon and Fisher, 2000; Clark \& Hammond, 1997; Fawcett et al., 2008; Frohlich, 2002; Hong \& Rao, 2010; Hult et al., 2004; Radjou, 2003). Research has shown that a firm needs to integrate information systems with key supply chain partners in order to facilitate improved information sharing and data exchange (Hult et al., 2007, 1037). Evidently, this was also supported through the results as a hundred percent are of the vies that advancement of technology have made internal network integration accessible to real time demand information visibility.

Wu et al. $(2014,123)$ states that in the demand chain, the advancement of technology has propelled the level of information sharing amongst planning partners. In today's operating environment, to improve the level of competitive advantage, supply chain partners have adopted networking concepts in order to facilitate information sharing (Ho et al. 2002, 4418). Promoting quality information sharing in the planning process produces significant performance improvements such as faster product developments, reduced lead times and higher flexibility in supply (Cachon \& Fisher 2000; Clark and Hammond 1997; Fawcett et al. 2008; Frohlich 2002; Hong \& Rao 2010; Hult et al. 2004; Radjou 2003). Research has shown that a firm needs to integrate information systems with key supply chain partners in order to facilitate improved information sharing and data exchange (Hult et al. 2007, 1037). This was also supported as the results showed that advancement of technology has made internal network integration accessible to real time demand information visibility. Information exchange is the key to managing physical product flow through the supply chain, as well as reducing costs and improving service performance of enterprises (Wu et al. 2014, 125).

\section{Perceptions on Information Sharing}

Respondents mostly agreed that information sharing achieves demand chain coordination and 
improves collaborative demand planning. With customers becoming more aware of their improved choices and demanding faster response times, shorter product cycle times and competitive products/services, business goals may be difficult to achieve if business units and supply chain partners continue to work in silos (Zhu, Gavirneni, \& Kapuscinski 2010, 175). This indicates that the benefits of information sharing and collaboration amongst planning partners can highly improve demand chain performance as organisations can provide what the customer wants. Another group of respondents agreed that an integrated electronic demand chain management system improves information sharing and an adequate IT infrastructure (Structural) was necessary to facilitate information sharing across stake holders (Planners, Sales and Production). The advancement of technology has mitigated the costs associated with information sharing and developments such as Enterprise Resource Planning (ERP) and Web technologies have improved the way in which this sharing can occur (Lotfi et al. 2013, 299). It is important to note that, partners in businesses are more willing to provide information on forecast and sales but are hesitant to share data on strategic and sensitive information, as supply chain members may choose to use it to their advantage (Fawcett et al. 2009, 224). The unwillingness to share such information contravene the benefits that arise from investments made for information sharing and relationships as there is unclear decision-making quality (Fawcett et al. 2011, 39).

\section{CONTRIBUTIONS OF STUDY TO KNOWLEDGE}

The study has been conducted to offer insight on demand chain planning operations within capacity constraints. Results may be valuable for role players as there are limited studies that focused on multiple variables in this field of supply chain management. Although there were no significant associations between the variables of interest in this study, the differences in the responses by the different categories depending on the position in the organisation silently communicates a message of some disjuncture between the views of those at operational level and those at leadership level.

\section{RECOMMENDATIONS ON THE ORGANISATION}

- Top management should provide full support to information sharing initiatives to facilitate the demand planning process
- Build a consensus demand plan amongst key stake holders

- Improved quality of information shared is required from external stakeholders for input in demand plans

- Plan capacity through time horizons (short, medium and long term) to allow better capacity flexibility in medium- and long-term horizon

\section{STUDY IMPLICATIONS AND SUGGESTIONS FOR FUTURE INVESTIGATION}

The implication of this study rest on that fact that organisations must do all in their power to share quality information based on trust with their partners, collaborating on demand to align forecast and gain a positive demand performance. The unique contribution of this study is that little has been done on demand chain management and this study bridges the gap in relation to information shared on demand planning. Future research is suggested that will include all the provinces where N ZAR operates. The tool used for data collection in this study will have to be revisited and subjected to the scrutiny of the practitioners in supply chain management, those in operational level and in academic institutions to ensure that the terminology used will be understood in an almost similar manner.

\section{CONCLUSION}

The focus was heavily placed on how the management of supply chains has changed, organisations and supply chain partners have chosen to take a demand chain management approach to running organisations. It was made evident that quality information sharing is a facilitator of the demand planning process and provides an opportunity to improve demand planning accuracy through the various stakeholders. Though information allows for connectivity in the demand chain, but it does not guarantee the protection of information that is shared. This factor prohibits partners to provide information freely. Quality of information shared is highly influenced by a shared vision amongst demand planning partners and top management support. Trust amongst internal and external partners as well as frequent interactions between demands planners were also noted as supporting factors to facilitating information sharing. The objective was to understand extent does sharing demand planning information improves demand chain performance. A collaborative demand plan that utilises information shared by various functions will ultimately 
result in an aligned forecast and improve demand chain performance. Highly positive views were expressed towards the statement that information sharing achieves demand chain coordination. This suggests that the benefits of information sharing and collaboration amongst planning partners can highly improve demand chain performance as organisations can provide what the customer wants. Therefore, it is essential for chain partner to actively provide information on factors that may influence demand.

\section{REFERENCES}

Abdullah, Z. \& Musa, R. (2014). "The effect of trust and information sharing on relationship commitment in supply chain management", Procedia - Social and Behavioral Sciences, 266-272.

https://doi.org/10.1016/j.sbspro.2014.04.031

Agrawal, D. K. (2012). Demand Chain management: Factors Enhancing Market Responsiveness Capabilities, Journal of Marketing Channels, 19: $101-119$. https://doi.org/10.1080/1046669X.2012.667760

Bakke, N. A., \& Hellberg, R. "The challenges in capacity planning", International Journal of Production Economics, (1993): 243264.

https://doi.org/10.1016/0925-5273(93)90096-4

Browning, T. \& Heath, R. (2009). "Reconceptualising the effects of lean on production costs with evidence from the F-22 program", Journal of operations management, 27(1), 23-44. https://doi.org/10.1016/j.jom.2008.03.009

Cachon, G.P., \& Fisher, M. (2000). "Supply chain inventory management and value of shared information", Management Science, 46(8), 1032-1048. https://doi.org/10.1287/mnsc.46.8.1032.12029

Chan, F. \& Chan, H. (2009). "Effects of cascade information sharing in inventory and service level in multi-echelon supply chains", Int. J. Bus. Perform. Supply Chain Modell, 1(1), 1-7. https://doi.org/10.1504/IJBPSCM.2009.026262

Chong, A.Y.L. \& Ooi, K.B. (2009). "Adoption of Interorganizational System Standards in Supply Chains: An Empirical Analysis of RosettaNet Standards", Industrial Management \& Data Systems, 108, 529-547. https://doi.org/10.1108/02635570810868371

Chong, A.Y.L., Ooi, K.B., \& Sohal, A. (2009). "The relationship between supply chain factors and adoption of e-collaboration tools: an empirical examination", Int. J. Prod. Econ, 122 (1), 150-160.

https://doi.org/10.1016/j.ijpe.2009.05.012

Chong, A.Y.L., Ooi, K.B., Lin, B., \& Tang, S.Y. (2009). "Influence of inter organizational relationships on SMEs 'e-business adoption", Internet Res, 19(3), 313 - 331. https://doi.org/10.1108/10662240910965379

Christopher, M. (2009). "Logistics and Supply Chain Management Creating Value-Adding Networks", Crainfield: Pearson Education Limited

Christopher, M., \& Rayls, L.J. (2014). "The Supply Chain Becomes the Demand Chain", Journal of Business Logistics, 35(1) 29 35. https://doi.org/10.1111/jbl.12037

Clark, T. \& Hammond, J. (2014). "Reengineering channel reordering processes to improve total supply chain performance", Production and Operations Management, 6(3), 248-265. https://doi.org/10.1111/j.1937-5956.1997.tb00429.x

Costantino, F., Di Gravio, G., Shaban, A. \& Tronci, M. (2014). "The impact of information sharing and inventory control coordination on supply chain performances", Computers and Industrial Engineering, 76, 292-306.

https://doi.org/10.1016/j.cie.2014.08.006

Danese, P. \& Kalchschmidt, M. (2011). "The role of the fore casting process in improving forecast accuracy and operational performance", Int. J. Production Economics, 131, 204-214. https://doi.org/10.1016/j.ijpe.2010.09.006

De Almeida, M. M. K., Martind, F. A. S., Salgado, A. M. P., Santos, F C. A. \& Da Silva, S. L. (2017). "The importance of trust and collaboration between companies to mitigate the bullwhip effect in supply chain management," Acta Scientiarum Technology, 39(2), 201-210. https://doi.org/10.4025/actascitechnol.v39i2.29648

Deshmukh, A. K. \& Mohan, A. (2016). Demand Chain management: The Marketing and Supply Chain Interface Redefined, Journal of Supply Chain Management, Vol. 13(1), 20 - 36.

Fawcett, S. E., Magnan, G. N. \& McCarter, M. W. (2008). "A threestage implementation model for supply chain collaboration", Journal of Business Logistics, 29(1), 93-112. https://doi.org/10.1002/j.2158-1592.2008.tb00070.x

Fawcett, S. E., Wallin, C., Allred, C. \& Magnan, G. (2009). "Supply chain information sharing: benchmarking a proven path", Benchmarking: An International Journal, 16(2), 222-246. https://doi.org/10.1108/14635770910948231

Fawcett, S. E., Wallin, C., Allred, C., Fawcett, A. \& Magnan, G. (2011). "Information technology as an enabler of supply chain collaboration: A dynamic capabilities perspective", Journal of Supply Chain Management, 47(1), 38-59. https://doi.org/10.1111/j.1745-493X.2010.03213.x

Frohlich, M.T. (2002). "E-integration in the supply chain: barriers and performance", Decision Sci, 33 (4), 537-556. https://doi.org/10.1111/j.1540-5915.2002.tb01655.x

Frohlich, M.T. \& Westbrook, R. (2002), "Demand chain management in manufacturing and services: web-based integration, drivers and performance", Journal of Operations Management, 20 (6), 729-745. https://doi.org/10.1016/S0272-6963(02)00037-2

Grimson, J.A. \& Pyke D.F. (2007), "Sales and Operations planning: an exploratory study and framework", International Journal of Logistics Management, 18 (3), 322-346. https://doi.org/10.1108/09574090710835093

Hax, A. C. \& H. C. Meal. (1975), "Hierarchical Integration of Production Planning and Scheduling", in Logistics of Studies in the Management Sciences, North-Holland/American Elsevier, (1).

Heizer, J. \& Render, B. (2011). "Principles of Operations Management', $8^{\text {th }}$ ed. New Jersey: Pearson Education.

Hong, P. \& Rao, S. S. (2010). "Supply management, supply flexibility and performance outcomes: An empirical investigation of manufacturing firms", Journal of Supply Chain Management, $46,6-22$ https://doi.org/10.1111/j.1745-493X.2010.03195.x

Hult, G. T., Ketchen, D. J. \& Slater, S. F. (2004). "Information processing, knowledge development, and strategic supply chain performance", Academy of Management Journal, 47(2), 243-253 https://doi.org/10.2307/20159575

Hult, G.T.M., Ketchen JR, D.J. \& Arrfelt, M. (2007). "Strategic Supply Chain Management: Improving performance through a culture of competitiveness and knowledge development", Strategic Management Journal, 28, 1035-1052. https://doi.org/10.1002/smj.627

Jonsson, P. \& Mattsson, S. (2013). "The Value of Sharing Planning Information in Supply Chains", International Journal of Physical Distribution and Logistics Management, 43, 4, 282299. https://doi.org/10.1108/IJPDLM-07-2012-0204

Jung, H., \& Jeong, S.J. (2012). "Managing demand uncertainty through fuzzy inference in supply chain planning", 
International Journal of Production Research, 50 (19), 54155429

https://doi.org/10.1080/00207543.2011.631606

Kilger, C., \& Wagner, M. (2010). "Demand Planning. In Stadtler, H., \& Kilger, C. (Ed.)", Supply chain management and advanced planning, 133-160.

https://doi.org/10.1007/978-3-540-74512-9_8

Kocoglu, I. Imamoglu, S.K. Ince, H. \& Keskin, K. (2011). "The effect of supply chain integration on information sharing: Enhancing the supply chain performance", Procedia Social and Behavioral Sciences, 24, 1630-1649. https://doi.org/10.1016/j.sbspro.2011.09.016

Kumar, G. \& Banerjee, R. N. (2014). "Strategy development by Indian SMEs for improving coordination in supply chain: an empirical study', Competitiveness Review, 24(5), 414-432. https://doi.org/10.1108/CR-06-2012-0016

Langabeer, J.R. \& Rose, J. (2002). “Creating Demand Driven Supply Chains: How to Profit from Demand Chain Management", Spiro Press, London.

Laseter, T. \& Oliver, K. (2003). "When will supply chain management grow up?", Strategy and Business, 32, 20-5.

Lee C.K.M., Ho, W., Ho, G.T.S., \& Lau H.C.W. (2011). "Design and development of logistics workflow systems for demand management with RFID", Expert Systems with Applications, 38 (5), 5428-5437

https://doi.org/10.1016/j.eswa.2010.10.012

Lee, H.L., Padmanabhan, V. \& Whang, S. (2011). "Information distortion in a supply chain: the bullwhip effect", Manag. Sci, 50 (12), 1875-1886. https://doi.org/10.1287/mnsc.1040.0266

Li J., Shaw M.J., Sikora R.T., Tan G.W. \& Yang R. (2002). "The effects of information sharing strategies on supply chain performance", College of Commerce and Business Administration, University of Illinois at Urbana-Champaign, URL: http://citebm. cba. uiuc.edu/B2Bresearch/ieee_em. Pdf 34.

Linne, A \& Ekhall, C. (2013). "Lean Capacity Planning", Master of Science.Chalmers University of Technology. Department of Technology Management and Economics.

Loretto, R., (2014) 'A new approach to effective demand planning' Journal of Business Forecasting, Summer 2014, 4-9

Lotfi, Z., Mukhtar, M., Sahran, S. \& Zadeh, A, T. (2013). "Information Sharing in Supply Chain Management", Procedia Technology, $298-304$ https://doi.org/10.1016/j.protcy.2013.12.194

Madhani, P.M. (2015). "Demand Chain Management: Enhancing Customer Lifetime Value through Integration of Marketing and Supply Chain Management", The IUP Journal of Business Strategy, 12(3), $7-27$

Montoya-Torres, J.R. \& Ortiz-Vargas, D. A. (2013). "Collaboration and information sharing in dyadic supply chains: A literature review over the period 2000-2012", Estudios Gerenciales, 30, 343-354. https://doi.org/10.1016/j.estger.2014.05.006

Morawetza, C. \& Sihna, W. (2012). "Model of a Decision Support System for a Least-Cost and Harmonized Capacity Adjustment in the Short- and Medium-Term Planning Horizon", Procedia CIRP, 3, 20 - 25 https://doi.org/10.1016/j.procir.2012.07.005

Nielsen, P. \& Steger-Jensen, K. (2006). "The Need for a Holistic Demand Planning Framework", International Conference on Information Systems, Logistics and Supply Chain (10).

Pandey V., Garg S., \& Shankar R. (2009). "Impact of information sharing on competitive strength of Indian manufacturing enterprises: An empirical study", Business Process Management Journal, 16, 226-243. https://doi.org/10.1108/14637151011035570
Radjou, N. (2009). "U.S. manufacturers' supply chain mandate", World Trade, 16 (12), 42-46.

Sekaran, U. \& Bougie, R. (2013). Research Methods for business, Southern Gate: John Wiley \& Sons Itd

Selen, W., \& Soliman, F. 2000). “Operations in today's demand chain management framework", Journal of Operations Management, $(20,667-673$. https://doi.org/10.1016/S0272-6963(02)00032-3

Septer, J., (2013). The Importance of an Enterprise Information Management Strategy. In: P. Baan, ed. Enterprise Information Management When Information Becomes Inspiration. New York: Springer-Verlag , pp. 43-79. Short, J., 2006. https://doi.org/10.1007/978-1-4614-5236-2_2

Shou, Z.G., Yang, L.H., Zhang, Q.Y., \& Su, C.T. (2013). "Market munificence and inter-firm information sharing: the moderating effect of specific assets", J.Bus.Res, 66, 2130 2138. https://doi.org/10.1016/j.jbusres.2013.02.039

Smith, L., Andraski, J., \& Fawcett, S.E. (2011). "Integrated Business Planning: A Roadmap to Linking S\&OP and CPFR.”, Journal of Business Forecasting, 29(4), 4-13. https://doi.org/10.1111/i.0000-0000.2012.01049.x

Stank, T.P., Esper, T.L., Crook, T.R., \& Autry, C.W. (2012). "Creating Relevant Value hrough Demand and Supply Integration.", Journal of Business Logistics, 33(2), 167-172.

Szozda N., \& Werbińska-Wojciechowska S. (2013). "Influence of the demand information quality on planning process accuracy in supply chain”, Case studies. LogForum LogForum, 9 (2), 7390

Triple Point Technology. (2012). "Reducing Risk in the Demand Planning Process, Process Manufacturing Research Study", Viewed 29 August 2015 http://www.tpt.com/resources/docs/ resources/Demand-Planning-RS.pdf

Tsung, F. (2002). "Impact of information sharing on statistical quality control. IEEE Trans. Syst. Man Cybern", Part A Syst. Humans, 30 (2), 211-216 https://doi.org/10.1109/3468.833103

Tyler, R. "Lean - No longer just for manufacturing. The Fortn advantage", 4th Quarter of 2003, p1.

Vlckova, V., \& Patak, M. (2011). "Barriers of demand planning implementation", Economics and Management, 16, 1000 1005.

Vurala, C. A. (2015). "Sustainable Demand Chain Management: An Alternative Perspective for Sustainability in the Supply Chain", Procedia - Social and Behavioral Sciences, 207: 262 -273 .

https://doi.org/10.1016/j.sbspro.2015.10.095

Wadhwa, S., \& Saxena, A. (2007). "Decision knowledge sharing: Flexible supply chains in KM context", Production Planning and Control London, 18(5), 436-452. https://doi.org/10.1080/09537280701450661

Wu, F., Yeniyurt, S., Kim, D., \& Cavusgil, S. T. (2006). "The impact of information technology on supply chain capabilities and firm performance: A resource-based view", Industrial Marketing Management, 35(4), 493-504. https://doi.org/10.1016/j.indmarman.2005.05.003

Wu, I.L., \& Chuang, C.H. (2010), "Analyzing contextual antecedents for the stage-based diffusion of electronic supply chain management", Electron. Com. Res. Appl, 8, 302-314. https://doi.org/10.1016/j.elerap.2009.04.013

Wu, I.L., Chuang, C.H. \& Hsu, C.H. (2014). "Information sharing and collaborative behaviors in enabling supply chain performance: a social exchange perspective", Int. J. Prod. Econ 148, 122-132. https://doi.org/10.1016/j.ijpe.2013.09.016 
Zhao X., Huo B., Selen W., \& Yeung J.H.Y. (2011). "The impact of internal integration and relationship commitment on external integration", Journal of Operations Management, (29), 17-32. https://doi.org/10.1016/j.jom.2010.04.004

Zhu, W., Gavirneni, S. \& Kapuscinski, R. (2010). "Periodic flexibility, information sharing, and supply chain performance", IIE Transactions; 42(3), $173-87$. https://doi.org/10.1080/07408170903394314
Zhu, D.S., Lee, Z.C., Ho, C.T., Hong, C.H., \& Lin, Y.J. (2014). "Will You Share? A Study of Motives and Consequences of Supply Chain Partners", Information Integration. An International Journal. 15 (2), 4-19.

https://doi.org/10.1080/16258312.2014.11517338

Received on 01-10-2019

Accepted on 13-11-2019

Published on 27-12-2019

DOI: https://doi.org/10.6000/1929-7092.2019.08.122

(C) 2019 Mtshali et al.; Licensee Lifescience Global.

This is an open access article licensed under the terms of the Creative Commons Attribution Non-Commercial License (http://creativecommons.org/licenses/by-nc/3.0/) which permits unrestricted, non-commercial use, distribution and reproduction in any medium, provided the work is properly cited. 